\title{
SURGICAL CORRECTION OF POSTTRAUMATIC NASAL DEFORMITIES IN ADOLESCENT ATHLETES
}

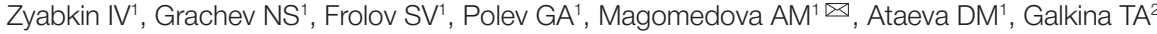

Federal Research and Clinical Center for Children and Adolescents of the Federal Medical Biological Agency, Moscow, Russia

${ }^{2}$ Burnazyan Federal Medical Biophysical Center of the Federal Medical and Biological Agency, Moscow, Russia

Nasal breathing is of great importance for professional athletes because of the peculiarities of carbon dioxide metabolism in the body. Problems with nasal breathing caused by post-traumatic deformities of the nose can be successfully corrected with the help of rhinoseptoplasty, but the possibility of performing this surgery on patients under 18 years of age is a discussed matter. This study aimed to analyze the results of the effect functional rhinoseptoplasty has on nasal breathing, consider rhinoseptoplasty as the preferred method of treatment for adolescents with post-traumatic deformities of the structures of the nose. The study involved 15 professional athletes aged 15-18 years with post-traumatic deformities of the external nose and troubled nasal breathing. Five of them (33.3\%) were female, 10 (66.7\%) were male; all underwent open rhinoseptoplasty. The NOSE and SCHNOS questionnaires were used to assess the symptoms of nasal obstruction before and after surgery. Post-surgery, all patients subjectively noted that their nasal breathing improved, which was confirmed by the filled questionnaires. There were no significant complications registered during the follow-up period. Functional rhinoseptoplasty is a viable surgical option for adolescents under 18 years of age.

Keywords: rhinoseptoplasty, septoplasty, rhinoplasty, adolescents, nasal breathing, pediatric rhinoseptoplasty

Author contribution: Zyabkin IV, Grachev NS, Frolov SV — study concept and design; Ataeva DM, Galkina TA - collection and processing of material; Magomedova AM — statistical data processing; Frolov SV, Magomedova AM — text authoring; Polev GA — editing; Frolov SV, Grachev NS — surgical treatment.

Compliance with ethical standards: the study was approved by the Ethics Committee of the Federal Research and Clinical Center for Children and Adolescents of the Federal Medical Biological Agency of Russia (Minutes \#1 of January 18, 2021), conducted in accordance with the principles of biomedical ethics formulated in the 1964 Declaration of Helsinki and its subsequent updates. All study participants signed informed voluntary consent.

Correspondence should be addressed: Aina M. Magomedova

Moskvorechye, 20, 115409, Moscow, Russia; aynamagomedova888@gmail.com

Received: 13.12.2021 Accepted: 21.12.2021 Published online: 23.12.2021

DOI: $10.47183 /$ mes.2021.047

\section{ХИРУРГИЧЕСКАЯ КОРРЕКЦИЯ ПОСТТРАВМАТИЧЕСКИХ ДЕФОРМАЦИЙ НОСОВЫХ СТРУКТУР У ПОДРОСТКОВ-СПОРТСМЕНОВ}

\author{
И. В. Зябкин ${ }^{1}$, Н. С. Грачев ${ }^{1}$, С. В. Фролов ${ }^{1}$, Г. А. Полев ${ }^{1}$, А. М. Магомедова ${ }^{\circledR}$, Д. М. Атаева ${ }^{1}$, Т. А. Галкина²
}

1 Федеральный научно-клинический центр детей и подростков Федерального медико-биологического агентства, Москва, Россия

2 Федеральный медицинский биофизический центр имени А. И. Бурназяна Федерального медико-биологического агентства, Москва, Россия

Носовое дыхание имеет большую значимость для профессиональных спортсменов в связи с особенностями метаболизма углекислого газа в организме. Затруднения носового дыхания, обусловленные посттравматическими десормациями носа, можно успешно корректировать с помощью риносептопластики, однако возможность ее проведения до 18 лет на сегодняшний день обсуждается. Целью исследования было изучить результаты влияния функциональной риносептопластики на носовое дыхание, рассмотреть возможность проведения риносептопластики в качестве предпочтительного метода лечения подростков с посттравматическими деформациями носовых структур. В исследовании участвовало 15 профессиональных спортсменов 15-18 лет с посттравматическими деформациями наружного носа и затруднением носового дыхания, из них 5 пациентов (33,3\%) - женского пола, 10 (66,7\%) - мужского пола, перенесшие риносептопластику открытым доступом. Для оценки симптомов назальной обструкции до и после операции использовали стандартизированные опросники NOSE и SCHNOS. Bсе пациенты, перенесшие хирургическое лечение, субъективно отмечают улучшение носового дыхания, что подтверждают результаты опросников. За период наблюдения не отмечено значимых осложнений. Функциональную риносептопластику можно рассматривать в качестве метода хирургического лечения у подростков младше 18 лет.

Ключевые слова: риносептопластика, септопластика, ринопластика, подростки, носовое дыхание, детская риносептопластика

Вклад авторов: И. В. Зябкин, Н. С. Грачев, С. В. Фролов - концепция и дизайн исследования; Д. М. Атаева, Т. А. Галкина - сбор и обработка материала; А. М. Магомедова - статистическая обработка данных; С. В. Фролов, А. М. Магомедова - написание текста; Г. А. Полев - редактирование; С. В. Фролов, Н. С. Грачев - хирургическое лечение.

Соблюдение этических стандартов: исследование одобрено этическим комитетом ФНКЦ детей и подростков ФМБА России (протокол № 1 от 18 января 2021 г.), проведено в соответствии с принципами биомедицинской этики, сформулированными в Хельсинкской декларации 1964 г. и ее последующих обновлениях. Все участники исследования подписали информированное добровольное согласие.

$\bigotimes$ Для корреспонденции: Айна Магомедовна Магомедова ул. Москворечье, д. 20, 115409, г. Москва, Россия; aynamagomedova888@gmail.com

Статья получена: 13.12.2021 Статья принята к печати: 21.12.2021 Опубликована онлайн: 23.12.2021

DOI: 10.47183/mes.2021.047

Troubled nasal breathing contributes to the development of many pathological changes in the upper respiratory tract: vasomotor rhinitis, sinusitis, dysfunction of the auditory tube, retraction of the tympanic membrane, etc. [1]. Children and adolescents that chronically cannot breathe well through the nose have the respiratory tract diseases accompanied with disorders of formation of facial structures, which entail various diseases of the entire dental-jaw system: hypoplasia of the middle third of the face, malocclusion, retrognathia, temporomandibular joint dysfunction, xerostomia etc. [2].
With mouth breathing, the level of aerodynamic resistance is lower and the volume of emitted carbon dioxide is higher This, in turn, leads to vasoconstriction, more frequent inhales that bring in more air, with subsequent hyperventilation, which has a negative effect on the functional parameters of the body. During physical activity, nasal breathing significantly reduces hyperventilation [3, 4].

The low sensitivity of chemoreceptors to carbon dioxide is one of the factors characterizing stamina during prolonged intense physical activity $[5,6]$. 
There are many anatomical and functional disorders that can make nasal breathing inadequate: inferior turbinates enlarged by vasomotor rhinitis, bullous middle turbinates, adenoid hypertrophy, etc. However, both for adolescents and adults, the most common reasons behind impeded nasal breathing are septal deviation and nasal valve insufficiency [1, 2].

Septoplasty is the well-known method of surgical treatment of deviations of nasal septum. However, in some cases, the results of classical septoplasty are unsatisfactory and the patient that underwent it does not have the ability to breathe through the nose restored. The protocol of this operation does not imply access large enough to reach all the nasal structures that were deformed. Septal deviations in the upper sections require other types of surgery, same as cicatricial and anatomical nasal valve stenosis, caudal septal deviations, pronounced post-traumatic deviations of the entire nasal pyramid with nasal septum deformations (Figure)

Whether it is possible and feasible to do rhinoseptoplasty on patients under 18 years of age is a matter of debate. For a long time, specialists did not consider rhinoseptoplasty an option for such patients due to the lack of convincing data on changes in the facial skeleton after surgery and popularity of the opinion that interventions into nasal structures have negative impact [7].

Initially, children and adolescents under 18 years of age were also not recommended to undergo septoplasty. However, in 1980 there were published the first studies the authors of which reported positive results of septoplasty in children and absence of post-surgery disturbances of growth of the nasal structures and the face. After that, the number of such studies has been growing steadily. Many functional and anthropometric indicators of facial structures were assessed, which allowed formulating the basic principles of the nasal structures growth and development in children and adolescents.

As of today, there are no exact data on the age at which nasal structures finally complete their formation and dimensional growth. According to some researchers, cartilage tissue continues to grow throughout life [9]. However, according to the data published by many authors who studied anthropometric characteristics of faces of children and adolescents, there are certain periods during which nasal structures, both bone and cartilage, complete their active and rapid growth and acquire the size and morphological outlook of an "adult" nose. According to the review, the so-called peak periods of growth occur at $13 \pm 1$ years in girls and $14 \pm 1$ years in boys [10].

To date, septoplasty has been proven safe for children from 6 years of age. As for rhinoseptoplasty, the respective research is in progress. The available data shows that surgical interventions associated with rhinoplasty do not lead to further changes in the facial skeleton, which allows considering rhinoplasty a surgery option for adolescents [8-10].

There has been published studies that describe large samples of patients under 18 years of age who underwent rhinoseptoplasty. One of them, published in 2011, covered cases of 202 patients (124 (61.4\%) male and 78 (38.6\%) female) aged 4-16 years (median age - 11 years) who underwent rhinoplasty and/or septoplasty between 1994 and 2010. Septoplasty was done in 157 (77.7\%) cases, rhinoseptoplasty in $23(11.4 \%)$ cases, rhinoplasty - in 22 cases (10.9\%). Complications were observed in $15.3 \%$ of patients: the largest number (14\%) was associated with recurring nasal septum deflection; $4.45 \%$ of patients has to have receptoplasty (3.5); in isolated cases, there were perforation $(0.5 \%)$ and synechiae (0.5) registered [11].

Another study described a cohort of 64 patients 4-17 years old who underwent rhinoseptoplasty from 2003 to 2011.
The researchers assessed anthropometric parameters before, immediately after and long after the operation, and noted lack of growth retardation or developmental disorders [12]. In such works, all authors note the absence of negative effects of rhinoseptoplasty on the ongoing growth of facial structures and suggest that girls have their nasal structures fully formed by the age of 13-14 years, boys - by the age of 15-16 years [13-15].

\section{METHODS}

This study included 15 patients aged 15-17 years, with the average age being 16.07 years. Five of them (33.3\%) were female, $10(66.7 \%)$ were male. All had post-traumatic deformities of the nasal septum and external nose and troubled nasal breathing. The participants underwent surgery in the period from January to October 2021 in the head and neck pathology surgical department of the Federal Research and Clinical Center for Children and Adolescents of the Federal Medical Biological Agency of Russia.

The degree of surgical intervention varied depending on the concomitant pathologies of the paranasal structures. The type of rhinoseptoplasty for all patients was open access; inferior turbinates were wave disintegrated.

Three participants also underwent simultaneous plastic closure of the nasal septum perforation. Two patients with severe external nose saddle deformity and perforation of the nasal septum had rhinoseptoplasty done with costal cartilage autograft.

All operations were performed under general anesthesia by one surgical team. All patients are professional athletes, 11 of them practicing contact sports: boxing, judo, Greco-Roman wrestling, etc.

The Nasal Obstruction Symptom Evaluation (NOSE) (Table 1) scale/questionnaire and the Russian-language adapted version of the Standardized Cosmesis and Health Nasal Outcomes Survey (SCHNOS) (Table 2) were used to assess the efficacy of surgical treatment. Both scales have high internal consistency with Cronbach's alpha $[16,17]$. The patients filled out the questionnaires before surgery and one month after it.

The NOSE scale offered to patients contains five main criteria: "nasal breathing difficulties", "nasal congestion", "nasal obstruction", "sleep problems", "nasal breathing

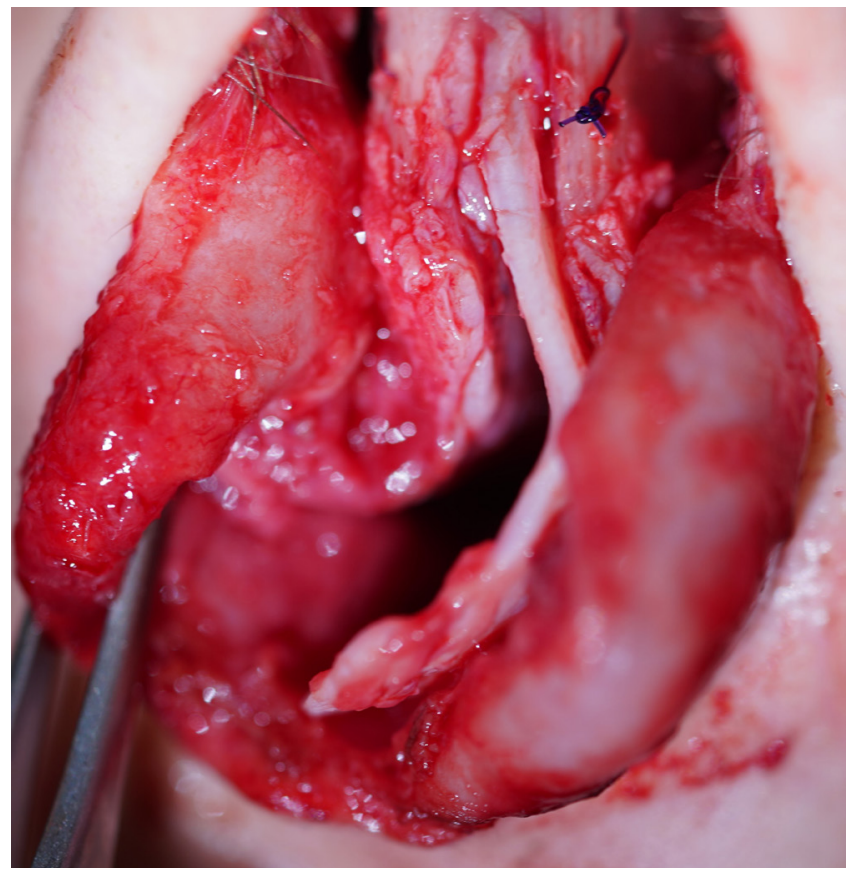

Fig. Severe deviation of the nasal septum (intraoperatively) 
Table 1. NOSE scale

\begin{tabular}{|l|c|c|c|c|c|}
\hline \multicolumn{1}{|c|}{ Symptom } & No problem & & & No problem \\
\hline Nasal congestion & 0 & 1 & 2 & 3 & 4 \\
\hline Nasal breathing difficulties & 0 & 1 & 2 & 3 & 4 \\
\hline Nasal obstruction & 0 & 1 & 2 & 3 & 4 \\
\hline Sleep problems & 0 & 1 & 2 & 3 & 4 \\
\hline $\begin{array}{l}\text { Nasal breathing insufficiency/inadequacy during } \\
\text { exercise }\end{array}$ & 0 & 1 & 2 & 3 & 4 \\
\hline
\end{tabular}

insufficiency during exercise." The severity of manifestation corresponds to the number of points: 0 points - no problem, 1 point - a minor problem, 2 points - a moderate problem, 3 points - a significant problem, 4 points - a very pronounced problem. Each patient assessed the criteria suggested in points from 0 to 4 before and one month after the operation. The score was calculated as the sum of the points multiplied by 5 . The SCHNOS scale follows the same principle: it relies on the Likert scale, however, it enables assessment of not only functional but also aesthetic criteria. For this purpose, the scale has two parts, items 1 through 4 for the functional criteria, 5 through 10 for aesthetic.

We used SPSS Statistics 23.0 software package (IBM; USA) with nonparametric methods to process the data statistically. The level of 0.05 was used as the critical level of reliability of the null statistical hypothesis of the absence of differences and influences.

\section{DISCUSSION}

All patients who underwent surgical treatment subjectively noted a significant improvement in nasal breathing.

The significance shown by the statistical analysis of the NOSE points given before and after the operation was 0.002 , which, at $p<0.05$, confirms that the number of points decreased and, accordingly, the quality of nasal breathing improved. The median before and after treatment was 50.00 and 5.00, respectively. The mean for the sample before treatment was 53.3, after treatment it was 8.3.

Statistical analysis of the SCHNOS scale data yielded the significance of 0.001 , which, at $p<0.05$, also confirms the decrease in the number of points. The median before and after surgical treatment was 70.0 and 5.0, respectively, mean 61.0 and 6.6.

Thus, according to the analyzed data obtained with the help of NOSE and SCHNOS questionnaires, one month after the treatment the number of points decreases significantly, which indicates an improvement in nasal breathing.

Postoperative complications occurred in three cases out of $15(20 \%)$; they were synechia of the nasal cavity; episode of nosebleeds in the early postoperative period; recurrence of vasomotor rhinitis. All complications were promptly arrested, no further relapse was observed.

\section{CONCLUSIONS}

During physical exercising of moderate and high intensity, nasal breathing allows achieving better functional results, which is especially important for professional athletes. For adolescents, rhinoseptoplasty may be the surgery of choice when there are specific deformities: nasal septum deflection in the upper sections, pronounced deviation in the caudal section, saddle nose deformity with insufficient nasal tissues, columella retraction; deformities of the nasal septum in combination with massive perforations; pronounced C-shaped post-traumatic deflection of the nasal pyramid with collapse of the nasal valves. According to the data published by foreign researchers and our own observations, rinoseptoplasty in female adolescents over 13 years old and male adolescents over 15 years old does not affect the further growth of facial structures.

Table 2. SCHNOS scale

\begin{tabular}{|c|c|c|c|c|c|c|c|}
\hline & Symptom & No problem & & & & & No problem \\
\hline \multirow{4}{*}{ 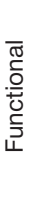 } & Troubled or fully obstructed nasal breathing & 0 & 1 & 2 & 3 & 4 & 5 \\
\hline & Nasal breathing during exercise & 0 & 1 & 2 & 3 & 4 & 5 \\
\hline & Nasal congestion & 0 & 1 & 2 & 3 & 4 & 5 \\
\hline & Nasal breathing during sleep & 0 & 1 & 2 & 3 & 4 & 5 \\
\hline \multirow{6}{*}{ 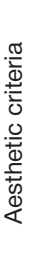 } & Impaired mood and self-esteem because of the nose & 0 & 1 & 2 & 3 & 4 & 5 \\
\hline & Nose tip shape & 0 & 1 & 2 & 3 & 4 & 5 \\
\hline & Straightness of the nose & 0 & 1 & 2 & 3 & 4 & 5 \\
\hline & Profile nose shape & 0 & 1 & 2 & 3 & 4 & 5 \\
\hline & Nose-and-face overall harmony & 0 & 1 & 2 & 3 & 4 & 5 \\
\hline & General symmetry of the nose & 0 & 1 & 2 & 3 & 4 & 5 \\
\hline
\end{tabular}




\section{References}

1. Lawrence R. Pediatric septoplasy: a review of the literature. Int $J$ Pediatr Otorhinolaryngol. 2012; 76 (8): 1078-81. DOI: 10.1016/j. ijporl.2012.04.020

2. Akgüner M, Barutçu $A$, Karaca $C$. Adolescent growth patterns of the bony and cartilaginous framework of the nose: a cephalometric study. Ann Plast Surg. 1998; 41: 66-69.

3. Morton AR, King K, Papalia S, Goodman C, Turley KR, Wilmore $\mathrm{JH}$. Comparison of maximal oxygen consumption with oral and nasal breathing. Aust J Sci Med Sport. 1995; 27 (3): 51-55.

4. Recinto C, Efthemeou T, Boffelli PT, Navalta JW. Effects of nasa or oral breathing on anaerobic power output and metabolic responses. Int J Exerc Sci. 2017; 10 (4): 506-14.

5. Lacomb C, Ovila P. Oral vs. nasal breathing during submaxima aerobic exercise. UNLV theses, dissertations, professional papers and capstones 2732. 2015; p. 122. Available from: http://dx.doi. org/10.34917/7645935

6. Dallam G, Kies B. The effect of nasal breathing versus oral and oronasal breathing during exercise: a review. Journal of Sports Research. 2020; 7 (1): 1-10.

7. Lawrence R. Pediatric septoplasy: a review of the literature International Journal of Pediatric Otorhinolaryngology. 2012; 76 (8): 1078-81.

8. Christophel JJ, Gross CW. Pediatric Septoplasty. Otolaryngologic Clinics of North America. 2009; 42 (2): 287-94.

9. Junusov AS, Bogomilskij M. Rinoseptoplastika $v$ detskom podrostkovom vozraste. M.: Gamma, 2001; s. 7. Russian.

\section{Литература}

1. Lawrence R. Pediatric septoplasy: a review of the literature. Int $J$ Pediatr Otorhinolaryngol. 2012; 76 (8): 1078-81. DOI: 10.1016/j ijporl.2012.04.020

2. Akgüner M, Barutçu A, Karaca C. Adolescent growth patterns of the bony and cartilaginous framework of the nose: a cephalometric study. Ann Plast Surg. 1998; 41: 66-69.

3. Morton AR, King K, Papalia S, Goodman C, Turley KR, Wilmore $\mathrm{JH}$. Comparison of maximal oxygen consumption with oral and nasal breathing. Aust J Sci Med Sport. 1995; 27 (3): 51-55.

4. Recinto C, Efthemeou T, Boffelli PT, Navalta JW. Effects of nasa or oral breathing on anaerobic power output and metabolic responses. Int J Exerc Sci. 2017; 10 (4): 506-14.

5. Lacomb C, Ovila P. Oral vs. nasal breathing during submaxima aerobic exercise. UNLV theses, dissertations, professional papers, and capstones 2732. 2015; p. 122. Available from: http://dx.doi. org/10.34917/7645935

6. Dallam $G$, Kies B. The effect of nasal breathing versus oral and oronasal breathing during exercise: a review. Journal of Sports Research. 2020; 7 (1): 1-10.

7. Lawrence R. Pediatric septoplasy: a review of the literature. International Journal of Pediatric Otorhinolaryngology. 2012; 76 (8): 1078-81.

8. Christophel JJ, Gross CW. Pediatric Septoplasty. Otolaryngologic Clinics of North America. 2009; 42 (2): 287-94.

9. Юнусов А. С., Богомильский М. Риносептопластика в детском и подростковом возрасте. М.: Гамма, 2001; с. 7.
10. Manteghi A, Din H, Bundogji N, Leuin SC. Pediatric septoplasty and functional septorhinoplasty: A quality of life outcome study. Int J Pediatr Otorhinolaryngol. 2018; 111: 16-20. DOI: 10.1016/j. ijporl.2018.05.016.

11. Maniglia CP, Maniglia JV. Rhinoseptoplasty in children. Braz J Otorhinolaryngol. 2017; 83 (4): 416-9.

12. Bae JS, Kim ES, Jang YJ. Treatment outcomes of pediatric rhinoplasty: The Asan medical center experience. Int $\mathrm{J}$ Pediatr Otorhinolaryngol. 2013; 77 (10): 1701-10.

13. Locke R, Kubba H. The external rhinoplasty approach for congenital nasal lesions in children. Int J Pediatr Otorhinolaryngol. 2011; 75: 337-41.

14. Kopacheva-Barsova G, Nikolovski N. Justification for rhinoseptoplasty in children - Our 10 years overview. Maced J Med Sci. 2016; 4 (3): 397-403

15. Kalantar-Hormozi A, Ravar R, Abbaszadeh-Kasbi A, Rita Davai N. Teenage Rhinoplasty. World J Plast Surg. 2018; 7 (1): 97-102.

16. Stewart MG, Witsell DL, Smith TL, Weaver EM, Yueh B, Hannley MT. Development and validation of the Nasal Obstruction Symptom Evaluation (NOSE) scale. Otolaryngol Head Neck Surg. 2004;130 (2): 157-63.

17. Zholtikov VV, Korableva NP, Lebedeva YuV, Saltychev M, Most SM, Mubaed S. P. Znachimost' russkogo perevoda Standartizirovannogo oprosnika dlja ocenki rezul'tata jestetiki funkcii nosa (SCHNOS). Plasticheskaja hirurgija i jesteticheskaja medicina. 2021; 2: 81-86. Russian.

10. Manteghi A, Din H, Bundogji N, Leuin SC. Pediatric septoplasty and functional septorhinoplasty: A quality of life outcome study. Int J Pediatr Otorhinolaryngol. 2018; 111: 16-20. DOI: 10.1016/j. ijporl.2018.05.016

11. Maniglia CP, Maniglia JV. Rhinoseptoplasty in children. Braz J Otorhinolaryngol. 2017; 83 (4): 416-9.

12. Bae JS, Kim ES, Jang YJ. Treatment outcomes of pediatric rhinoplasty: The Asan medical center experience. Int J Pediatr Otorhinolaryngol. 2013; 77 (10): 1701-10.

13. Locke R, Kubba $H$. The external rhinoplasty approach for congenital nasal lesions in children. Int J Pediatr Otorhinolaryngol. 2011: 75: 337-41.

14. Kopacheva-Barsova G, Nikolovski N. Justification for rhinoseptoplasty in children - Our 10 years overview. Maced J Med Sci. 2016; 4 (3): 397-403.

15. Kalantar-Hormozi A, Ravar R, Abbaszadeh-Kasbi A, Rita Davai N Teenage Rhinoplasty. World J Plast Surg. 2018; 7 (1): 97-102.

16. Stewart MG, Witsell DL, Smith TL, Weaver EM, Yueh B, Hannley MT. Development and validation of the Nasal Obstruction Symptom Evaluation (NOSE) scale. Otolaryngol Head Neck Surg. 2004;130 (2): 157-63.

17. Жолтиков В. В., Кораблева Н. П., Лебедева Ю. В., Салтычев М., Мост С. М., Мубаед С. П. Значимость русского перевода Стандартизированного опросника для оценки результата эстетики и функции носа (SCHNOS). Пластическая хирургия и эстетическая медицина. 2021; 2: 81-86. 